\title{
Foreign Direct Investment and Minimum Spanning Tree
}

\author{
Eryigit Mehmet \\ Prof. İzzet Baysal University, Turkey,
}

\begin{abstract}
This study aims to examine complex foreign direct investment (FDI) inflows and outflows between OECD member countries. Foreign direct investment (FDI) covers activities of a nonlocal company in a foreign country. Foreign direct investments inward and outward flows between OECD countries will be investigated. The main difference between foreign direct investment and other portfolio investments is the degree of control on decision making and production processes (Aktepe, 2004). The literature, generally, focus on factors affecting FDI. Yet, we could not encountered any study dedicated to determine the FDI links between countries. This study aims to fill this gap in the literature. Foreign direct investment links between countries are identified through using Minimum Spanning Tree (MST) and Complex Networks approaches. MST approach determines the patterns presenting international foreign direct investments flows. According to the results of the MST, United States is the dominant country for the FDI inward and outward flows.
\end{abstract}

Keywords: Complex Networks, Foreign Direct Investment.

\section{Introduction}

Foreign direct investment (FDI) covers activities of a nonlocal company in a foreign country. A foreign company can invest into a foreign country through different ways as (a) greenfield investment, (b) opening a subsidiary/branch, (c) equity investment (d) buying at least 10\% shares of stocks on a stock market (Hazine Müsteşarlığı 2006). The main difference between foreign direct investment and other portfolio investments is the degree of control on decision making and production processes (Aktepe, 2004). Although flow of FDI between countries is not as easy as portfolio investments, the amount of FDI has been increasing recently. The literature, generally, focus on factors affecting FDI. Yet, we could not encountered any study dedicated to determine the FDI links between countries. This study aims to fill this gap in the literature.

An international company is likely to make FDI if foreign market structure provides opportunity to achieve the company's long term goals. Generally, foreign markets are evaluated based on market size, political stability, civil order, duties and subsidies (Aktepe 2004). FDI should be regarded as a two way trade. The countries that attracts the most of the world total FDI are the ones that make the most of the world total FDI. Figure 1 shows the FDI inward flows in 2015. According to Figure 1, in 2015, USA, China, Ireland and Hongkong are the highest ranked countries. Turkey is the 17th country with $\$ 17$ billion FDI. Figure 2 shows the FDI outward flows in 2015. Accordingly, USA, China, Ireland and Holland are the highest ranked countries. Turkey is the last with $\$ 5$ billion FDI. 


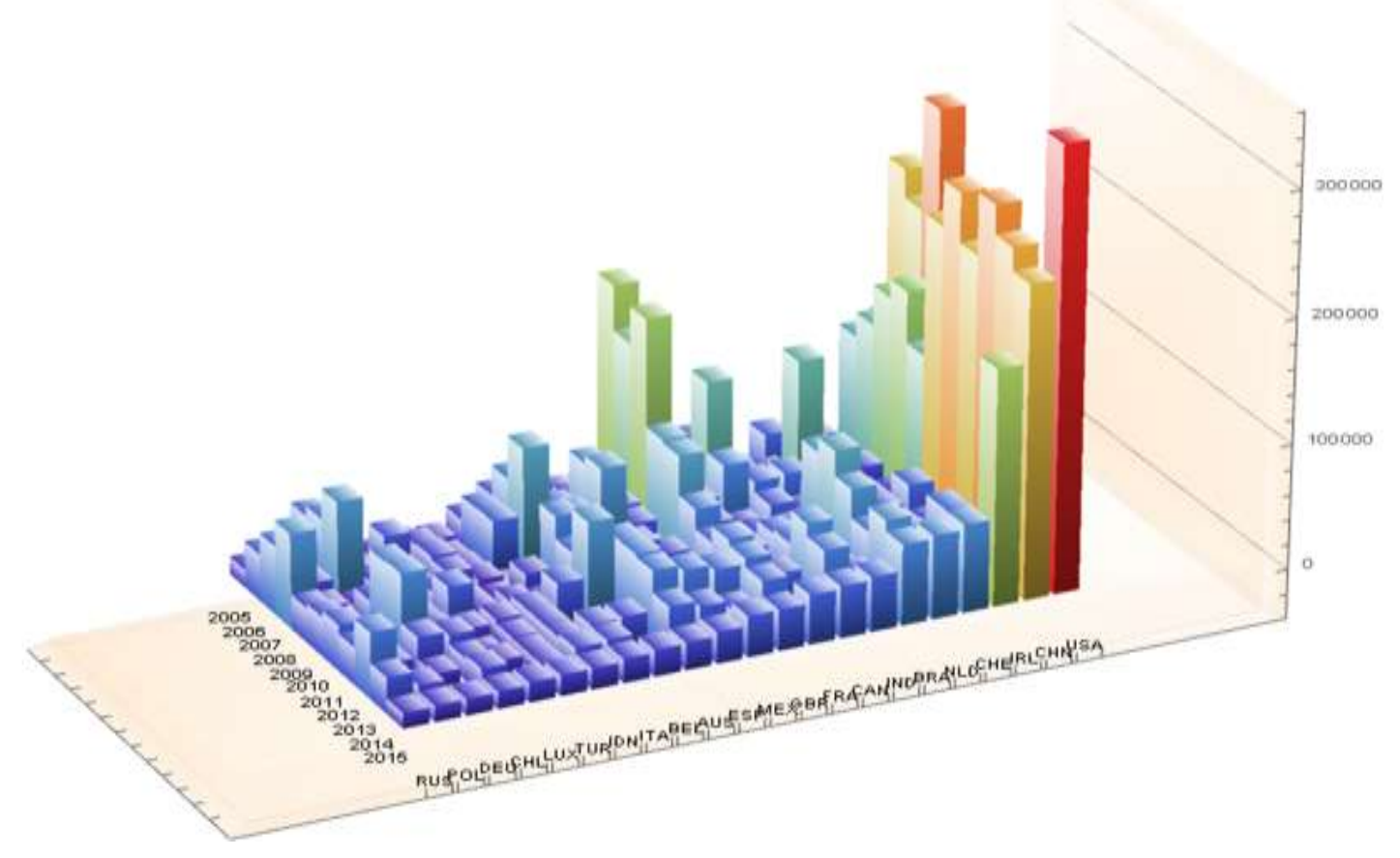

Fig. 1: Fdi Inward Flows

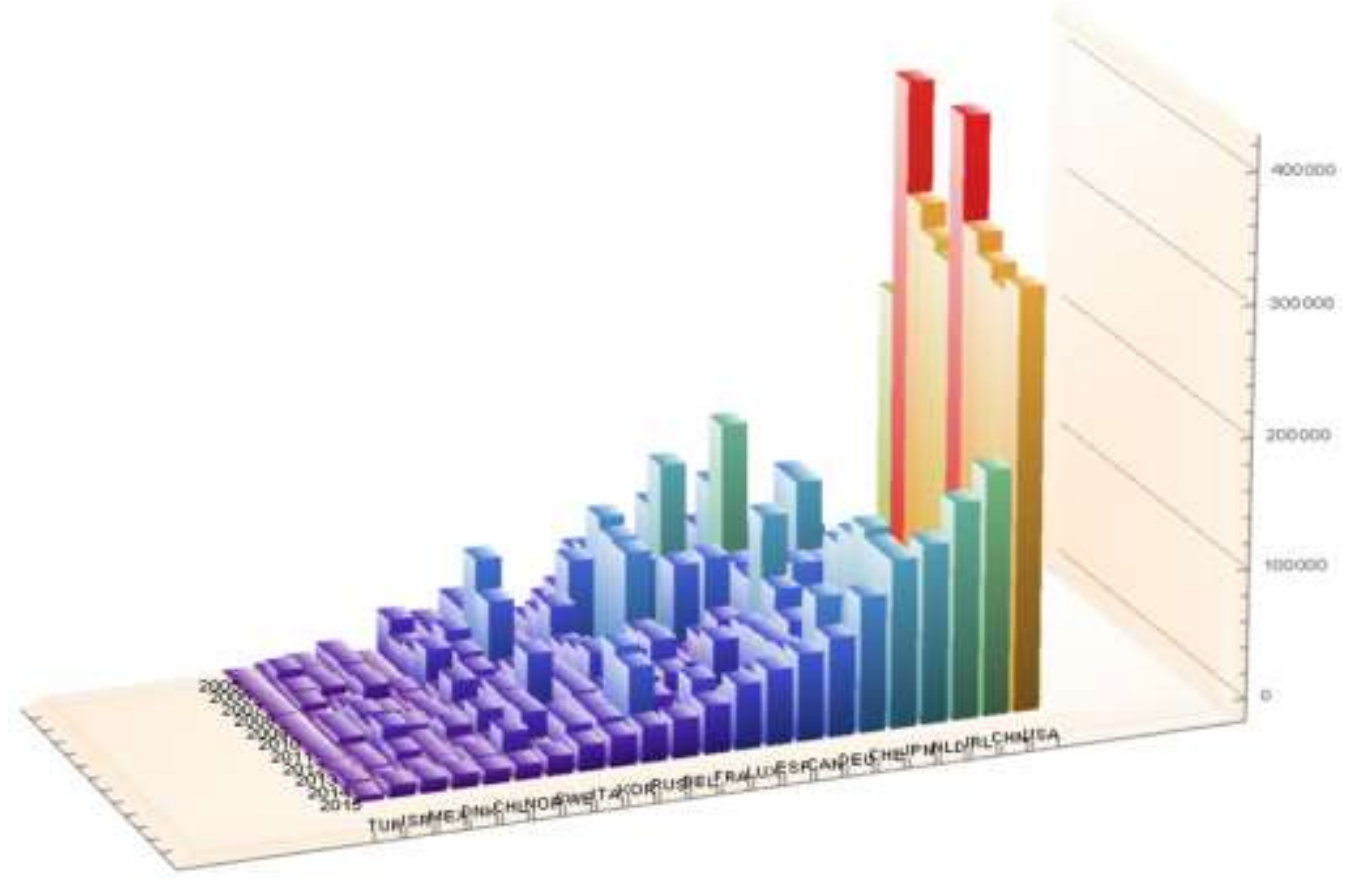

Fig. 2: FDI Outward Flows

To understand the patterns of the FDI flows (inward and outward), we have to apply some criteria to extract the connected networks. In this study we applied the minimum spanning tree to extract the FDI connections. We generated the FDI inward and outward network for each year from 1986 to 2013 . We applied the Kruskal's algorithm to extract the minimum spanning tree from connected FDI. 


\section{Literature}

The literature on FDI widely focused on factors affecting flow of FDI among countries. Some of the factors that are examined are bilateral trade volume (Liu et. al.., 2001), GDP (Hsiao and Hsiao, 2006), market size, country risk, gold reserves, share of industry in GDP (Bevan and Estrin, 2000), exchange rate, diplomatic relations, bilateral trade, and distance (Pan, 2003).

Approaches like Minimum Spanning Tree and Complex Network Structure have been adopted to examine stock exchanges (Mantegna, 1999; Miccichè et. al., 2003; Bonanno, 2004; Eom et. al., 2009; Eryiğit and Eryiğit, 2009), to solve assignment problems (Held and Karp, 1970), and analyze international trade (Kantar et. al., 2011; Geng et. al., 2014).

In this study, global network structures of FDI inward flows and FDI outward flows are analyzed using Minimum Spanning Tree and Complex Network Structure approaches. The study examines complex network of FDI among countries for the period of 1986 and 2013.

\section{Methodology and Analysis}

\subsection{Data}

The data for FDI inward flows and FDI outward flows are gathered OECD database. The data are used as a single currency (USD) and from reporting country. Outward flows represent transactions that increase the investment that investors in the reporting economy have in enterprises in a foreign economy, such as through purchases of equity or reinvestment of earnings, less any transactions that decrease the investment that investors in the reporting economy have in enterprises in a foreign economy, such as sales of equity or borrowing by the resident investor from the foreign enterprise. Inward flows represent transactions that increase the investment that foreign investors have in enterprises resident in the reporting economy less transactions that decrease the investment of foreign investors in resident enterprises (OECD, 2017).

\subsection{Methodogy and Analysis}

We generated the minimum spanning tree (MST) from densely connected Foreign Direct Investment (FDI) inward and outward flows data. We set the strength of the link between countries as $g_{i j}(t)=\frac{1}{w_{i j}(t)}$ where we calculate the $w_{i j}(t)=\left(f d_{i j}(t)+f d_{j i}(t)\right) / 2$. $f d_{i j}(t)$ denotes the money flowing as FDI into the country i from country $\mathrm{j}$ at the year $\mathrm{t}$. Similarly, $f d_{j i}(t)$ corresponds to the money flowing as FDI from country $\mathrm{j}$ to the country $i$ at the year t. $w_{i j}(t)$ defined as link strenght between the country $i$ and the country $\mathrm{j}$. The large $w_{i j}(t)$ means that FDI flows between two countries heavly and they interact strongly by the FDI relationship. If the $w_{i j}(t) \neq 0$ (taht's there is a FDI flow between two countries) we set the adjacency matrix $a_{i j}(t)=1$ at each year $t$. In the FDI connected network, the node degree is defined as $k_{i}=\sum_{j} a_{i j}$. The node degree is equal to the number of FDI partners at the year (Maeng, et al., 2012). The node strength is defined as $s_{i}=\sum_{j} w_{i j}$. The node strenght is a measure of the weighted connectivity. After the calculation of the $w_{i j}(t)$, we extract the MST by using Kruskal's algorithm. The network of the FDI outward between countries is in figure 3 (at year 1990 and 2013). In MST there are N nodes and N-1 links. After using MST to the foreign direct investment outward flow, the network can be seen as in figure 4 for the outward FDI. 
12th International Conference on Business, Social Sciences, Humanities and Education (BSSHE-18) March 13-14, 2018 Kuala Lumpur (Malaysia)

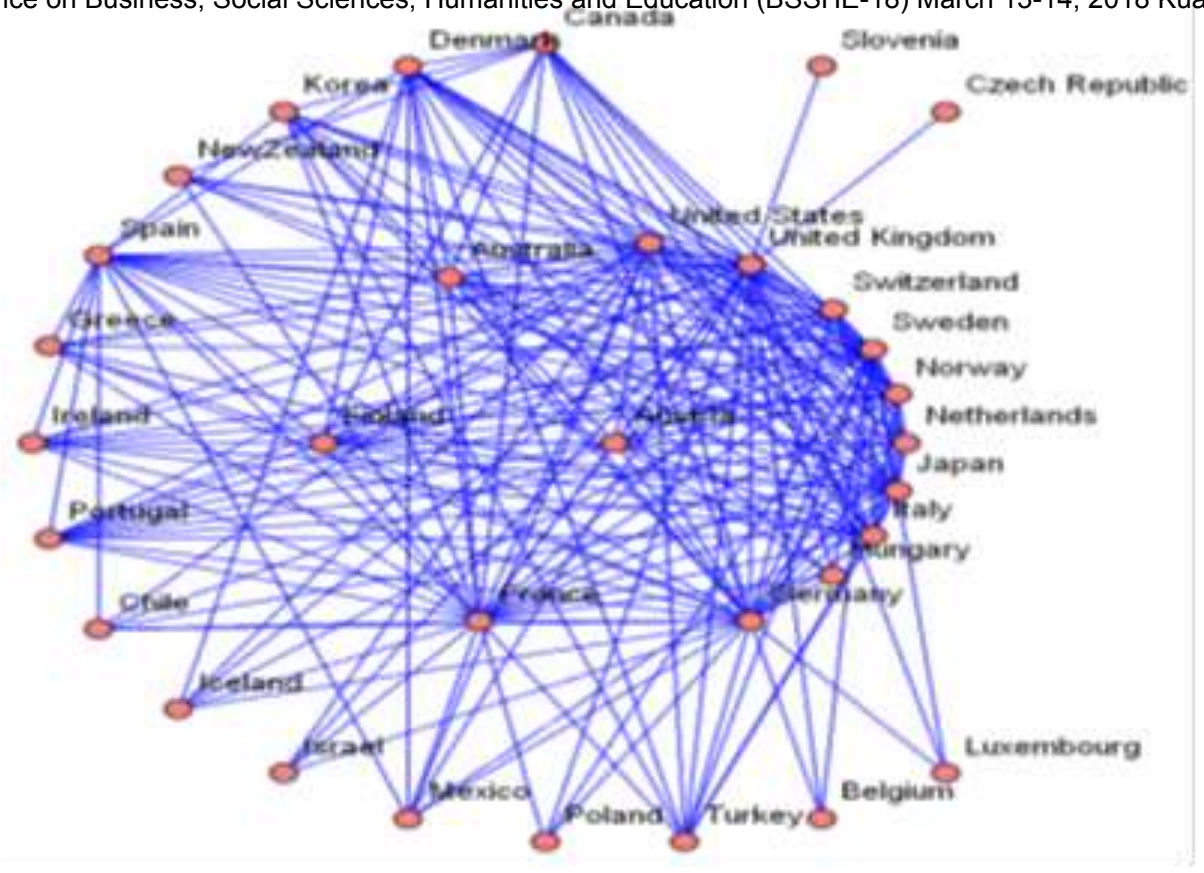

year 1990

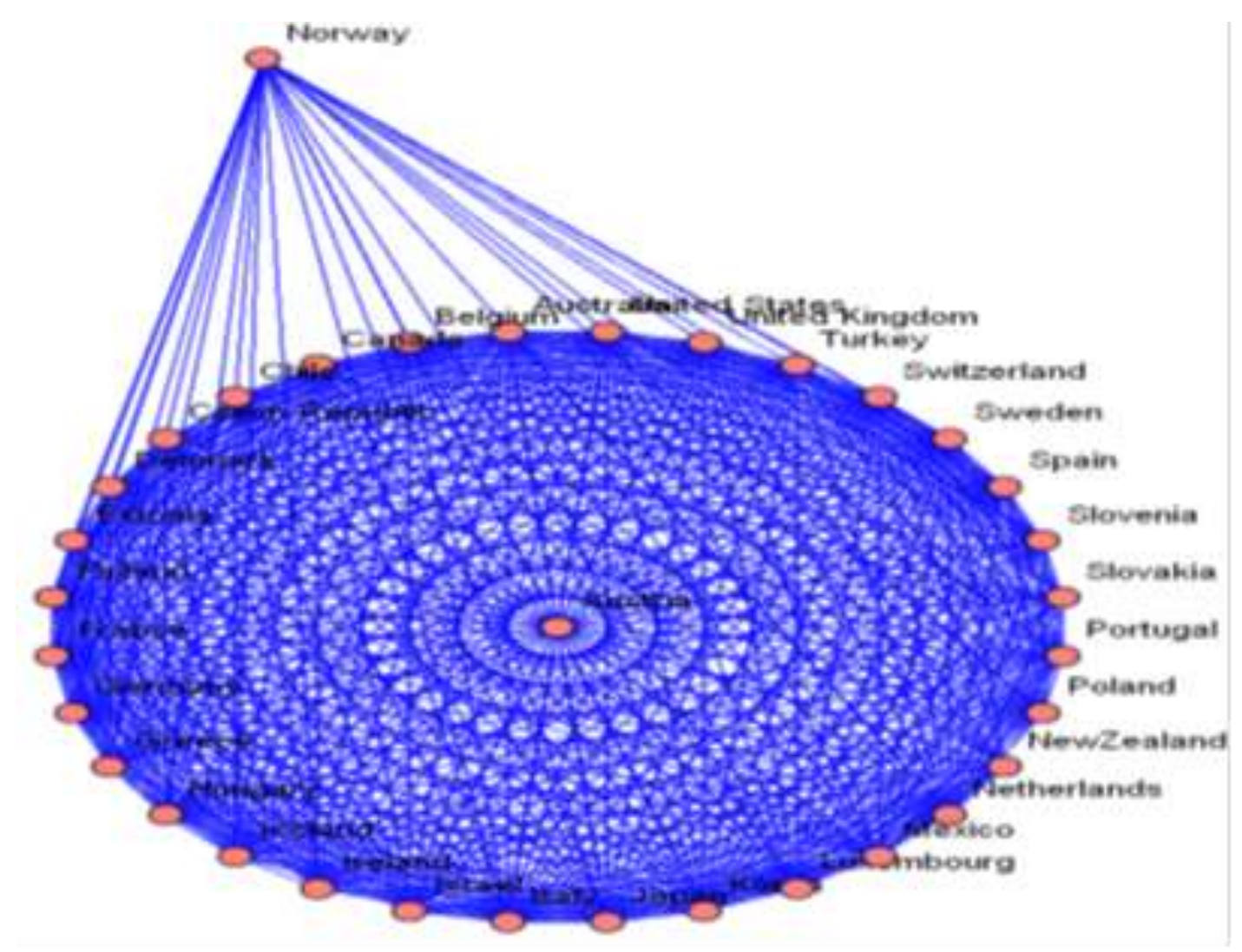

year 2013

Fig. 3: Outward FDI flows and networks between countries

From the MST we can identify the foreign direct investment links among the countries. Also, we can see the FDI zones among those OECD countries. Figure 4 show us that at year 1990, United States is the dominant 
country. If we cut the connection of this country with its connecting countries, we can see the secondary FDIoutward hubs are the United Kingdom. But at year 2013, Luxembourg is the dominant country and the secondary hub countries are Belgium, United Kingdom and United States.
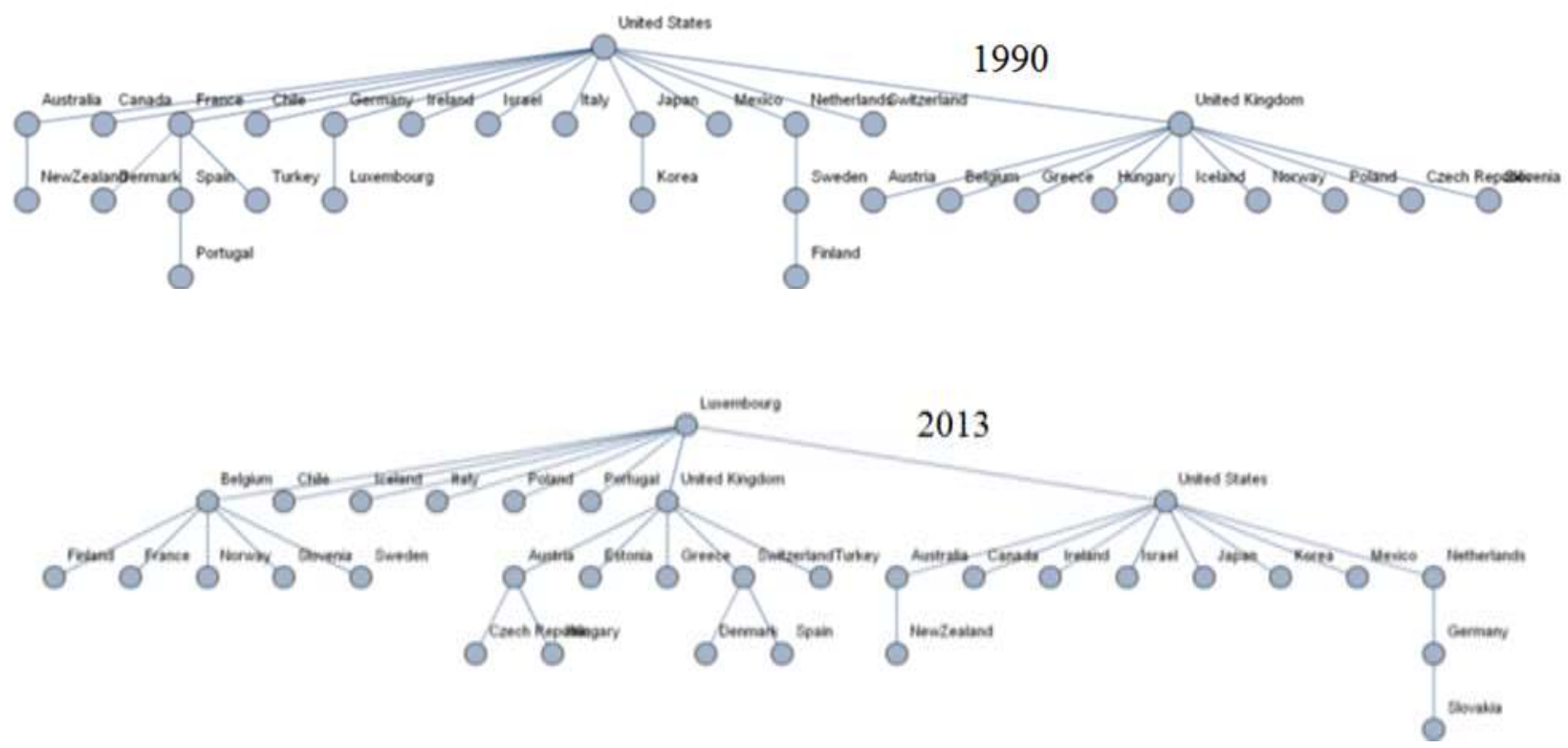

Fig. 4: Minimum Spanning Tree of the FDI-outward network

Similar with FDI outward flow, when we apply MST to the foreign direct investment inward flows, figure.5 shows us that at year 1990, the main hub country is United States, and the second hub country is United Kingdom. But at year 2013, according to the FDI inward flows, the dominant countries are Luxembourg and the United States.
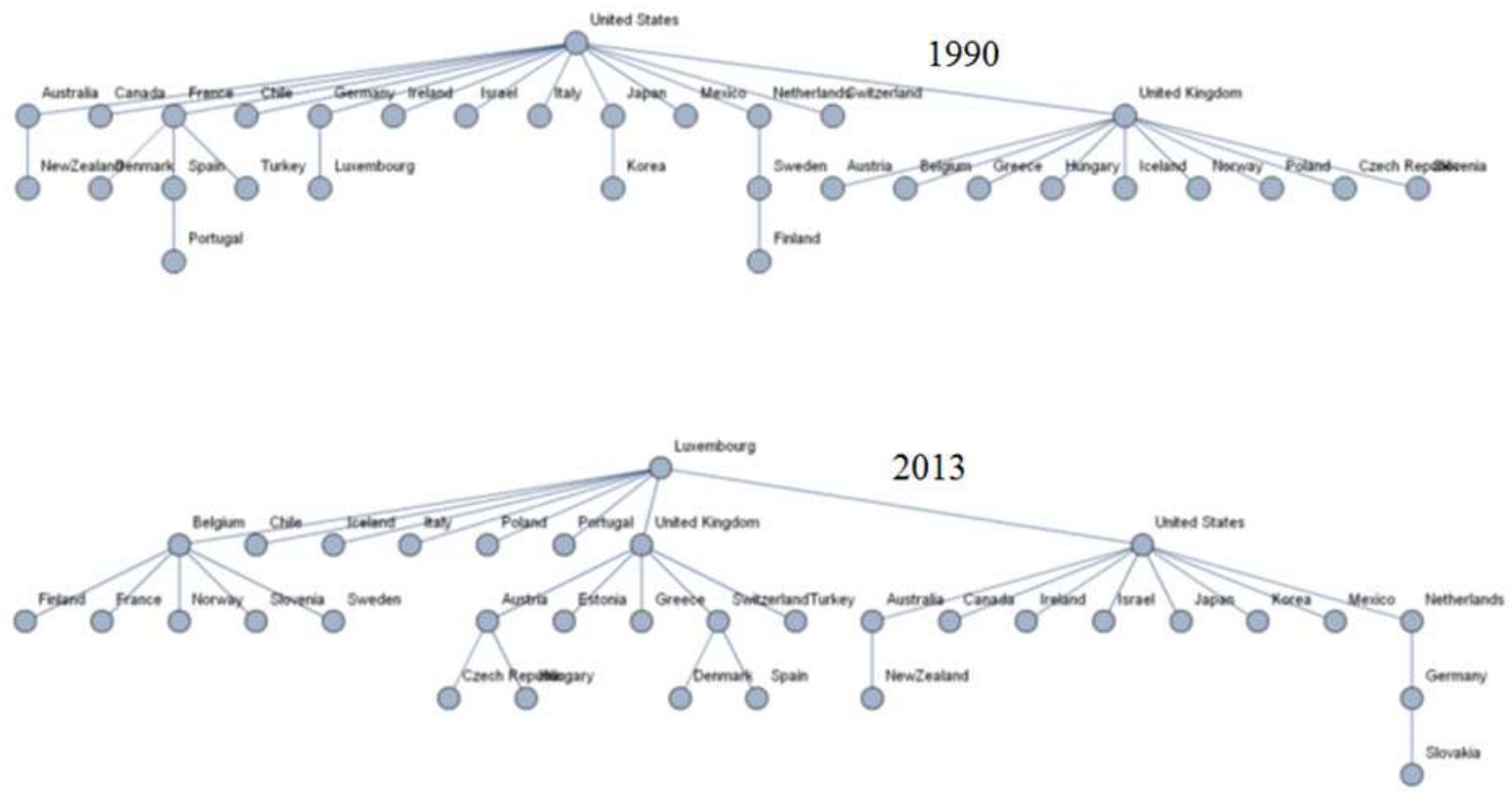

Fig. 5: Minimum Spanning Tree of the FDI-inward network 


\section{Conclusion}

We revied the complex network and minimum spanning tree of the foreign direct investment outward and inward flows networks among the OECD member countries. In the MST, Luxembourg (at year 2013) and United States (at year 1990) are the dominant hub node for the FDI outward, but United States is a dominant hub node for the FDI inwward in year 1990 and year 2013.

\section{References}

[1] Aktepe, C., (2004). Türkiye'de Gerçekleşmiş Doğrudan Yabancı Sermaye Yatırımlarının Eklektik Paradigma Çerçevesinde İncelenmesi, Doktora Tezi, Hacettepe Üniversitesi, Ankara.

[2] Bevan, A. A. \& Estrin, S., The Determinants of Foreign Direct Investment in Transition Economies (December 2000). CEPR Discussion Paper No. 2638. Available at SSRN: https://ssrn.com/abstract=258070

[3] Bonanno, G., Caldarelli, G., Lillo, F., Micciche, S., Vandewalle, N., \& Mantegna, R. N. (2004). Networks of equities in financial markets. The European Physical Journal B-Condensed Matter and Complex Systems, 38(2), 363-371. https://doi.org/10.1140/epjb/e2004-00129-6

[4] Eryiğit, M., \& Eryiğit, R. (2009). Network structure of cross-correlations among the world market indices. Physica A: Statistical Mechanics and its Applications, 388(17), 3551-3562.

[5] https://doi.org/10.1016/j.physa.2009.04.028

[6] Eom, C., Oh, G., Jung, W. S., Jeong, H., \& Kim, S. (2009). Topological properties of stock networks based on minimal spanning tree and random matrix theory in financial time series. Physica A: Statistical Mechanics and its Applications, 388(6), 900-906.

[7] https://doi.org/10.1016/j.physa.2008.12.006

[8] Geng, J. B., Ji, Q., \& Fan, Y. (2014). A dynamic analysis on global natural gas trade network. Applied Energy, 132, 23-33.

[9] https://doi.org/10.1016/j.apenergy.2014.06.064

[10] Held, M., \& Karp, R. M. (1970). The traveling-salesman problem and minimum spanning trees. Operations Research, 18(6), 1138-1162.

[11] https://doi.org/10.1287/opre.18.6.1138

[12] Hsiao, F. S. T., \& Hsiao, M. W. (2006). FDI, Exports, and Growth in East and Southeast Asia: Evidence from TimeSeries and Panel Data Causality Analyses. Paper presented at 2006 International Conference on Korea and the World Economy $V$, Seoul, Korea.

[13] Liu, X., Wang, C. \& Wei, Y. (2001). "Causal links between foreign direct investment and trade in China", China Economic Review, 12, 190-202 https://doi.org/10.1016/S1043-951X(01)00050-5

[14] Maeng, S.E., Choi, H. W., \& Lee, J. W., (2012). "Complex Networks and Minimal Spanning Trees in International Trade Network”, Int. J. Mod. Phys. Conf. Ser. 16, 51. https://doi.org/10.1142/S2010194512007775

[15] Mantegna, R. N. (1999). Hierarchical structure in financial markets. The European Physical Journal B-Condensed Matter and Complex Systems, 11(1), 193-197. https://doi.org/10.1007/s100510050929

[16] OECD (2017), FDI flows (indicator). doi: 10.1787/99f6e393-en (Accessed on 30 August 2017) https://doi.org/10.1787/99f6e393-en 